\title{
GLOBAL ECONOMIC CRISIS: CAUSES, IMPACT ON INDIAN ECONOMY, AGRICULTURE AND FISHERIES
}

\author{
APU DAS ${ }^{1 *}$, KUMAR N.R. ${ }^{1}$, BISWAJIT DEBNATH ${ }^{1}$ AND MANDAL S.C. ${ }^{2}$ \\ ${ }^{1}$ Central Institute of Fisheries Education (CIFE), Mumbai-400061, Maharashtra, India. \\ ${ }^{2}$ College of Fisheries, CAU, Lembucherra, Agartala, 799210, Tripura, India. \\ *Corresponding Author: Email- apudascifefec04@gmail.com
}

Received: April 28, 2012; Accepted: May 21, 2012

\begin{abstract}
The global economic crisis started in United States of America mainly due to 'sub-prime mortgages' where interest rate was slower down and there was a great demand for housing loans. Later, American banks repackaged this debt to worldwide financial instruments called 'Collateralized debt obligations' and sold them worldwide, which resulted in unaffordable mortgage payments and many people defaulted or undertook foreclosure. Then this mortgages crisis affected worldwide. Different views on the reasons of the crisis include subprime mortgage, securitization and repackaging of loans, excessive leverage, mismatch between financial innovation and regulation, fair value accounting rules, typical characteristics of US financial system, failure of global corporate governance \& complex interplay of multiple factors. Developed countries have so far been the most affected, with a decline in FDI inflows in 2008, mainly due to sluggish market prospects. Flows into developing economies continued to grow in 2008, but at a much lower rate than the year before. Indian economy and agriculture cannot be completely insulated from the global and domestic economic recessions. The impact of economic crisis on Indian agriculture and fisheries were transmitted through three distinct channels, viz., financial sector, exports and exchange rates, and the impact manifests itself in several direct and indirect ways. Some of the impacts were decreased GDP growth rate, high inflation, FDI inflows and international trade.
\end{abstract}

Key words- Global economic crisis, Sub-prime mortgages, Gross Domestic Product (GDP), Foreign Direct Investment (FDI).

Citation: Apu Das, et al. (2012) Global Economic Crisis: Causes, Impact on Indian Economy, Agriculture and Fisheries. International Journal of Agriculture Sciences, ISSN: 0975-3710 \& E-ISSN: 0975-9107, Volume 4, Issue 4, pp-221-226.

Copyright: Copyright@2012 Apu Das, et al. This is an open-access article distributed under the terms of the Creative Commons Attribution License, which permits unrestricted use, distribution, and reproduction in any medium, provided the original author and source are credited.

\section{Introduction}

Banking and economic crises have been a common phenomenon throughout the modern economic history of mankind. Since the great depression of 1929, the world has witnessed hundreds of such crises and the frequency of the crises has increased over time. According to a UNCTAD (2008a), there were as many as 112 systemic banking crises from the late 1970s until 2001. Most of them, including the current one, have shared some common features: they each started with a hasty process of financial sector reforms, which not only created a vacuum in terms of regulations but also deteriorated the basic economic fundamentals though massive inflows of foreign capital and finally ended up with a change in investor expectations and a consequent mess in the financial markets. Seshan (2009) reported that the financial sector crisis that arose in the latter half of 2007 and was precipitated by the collapse of Lehman Brothers on 23 September 2008 shared most of these features. However, what makes the current crisis exceptional is that it broke out at the very epicentre of global capitalism and its contagion spread very quickly to the entire globe. India, being an integrated part of the global economic order, was also exposed to the adverse impact of the global economic crisis. The Indian economy looked to be relatively insulated from the global financial crisis that started in August 2007 when the 'subprime mortgage' crisis first surfaced in the US. But as the financial meltdown, morphed in to a global economic downturn with the collapse of Lehman Brothers on 23 September 2008, the impact on the Indian economy was almost immediate. Credit flows suddenly dried-up and, overnight, money market interest rate spiked to above 20 percent and remained high for the next month. It is, perhaps, judicious to assume that the impacts of the global eco- 
nomic downturn, the first in the centre of global capitalism since the Great Depression, on the Indian economy are still unfolding. For the first time in 60 years, the IMF (2011) is now reported a global recession with negative growth for world GDP in 2009-10. The Horn (2010) has reported that GDP virtually collapsed in the second half of 2008 and further it declined by as much as nine percent in 2009-10.

\section{Methodology}

The data for the study has been collected from secondary sources. The present study focused on origin of the global economic crisis and the impact on Indian economy, agriculture and fisheries.

\section{Result and Discussion \\ Causes of Economic crisis \\ i. Sub-prime mortgage}

G-20 summit (2008) viewed that the current global economic crisis has originated due to sub-prime mortgage in USA in 2007. With easy availability of credit at low interest rates, real estate prices in US had been rising rapidly since the late 1990s and investment in housing had assured financial return. Kunt et al., (2002) reported that US home-ownership rates rose over the period 1997-2005 for all regions, all age groups, all racial groups, and all income groups. Banks went out of their way to lend to sub-prime borrowers who had no collateral assets. Low income individuals who took out risky sub-prime mortgages were often unaware of the known risks inherent in such mortgages. While on the one hand, they were ever keen to become house-owners, on the other, they were offered easy loans without having any regard to the fact that they were not in a position to refinance their mortgages in the event of the crisis. All this was fine as long as housing prices were rising. But the housing bubble burst in 2007. Home prices fell between 20 per cent and 35 per cent from their peak and in some areas more than 40 per cent; mortgage rates also rose. Sub-prime borrowers started defaulting in large numbers. The banks had to report huge losses. Acharya (2009), Green, King \& Dawkins (2010) also explain the main reason of global economic crisis is excessive subprime mortgages.

\section{ii. Securitization and Repackaging of Loans}

The mortgage market crisis that originated in the US was a complex matter involving a whole range of instruments of the financial market that transcended the boundaries of sub-prime mortgage. An interesting aspect of the crisis emanated from the fact that the banks/ lenders or the mortgage originators that sold sub-prime housing loans did not hold onto them. They sold them to other banks and investors through a process called securitization. Securitization, as a financial process, has gained wide currency in the US in the last couple of decades. Indeed, as recently as 1980 only 10 per cent of US mortgages were securitized compared to 56 per cent in 2006. In the context of the boom in the housing sector, the lenders enticed the naive, with poor credit histories, to borrow in the swelling sub-prime mortgage market. They originated and sold poorly underwritten loans without demanding appropriate documentation or performing adequate due diligence and passed the risks along to investors and securitizes without accepting responsibility for subsequent defaults. These sub-prime mortgages were securitized and re-packaged, sold and resold to investors around the world, as products that were rated as profitable investments. They had a strong incentive to lend to risky borrowers as investors, seeking high returns and were eager to purchase securities backed by sub-prime mortgages. The booming housing sector brought to the fore a system of repackaging of loans. It thrived on the back of flourishing mortgage credit market. The system was such that big investment banks such as Merrill Lynch, Morgan Stanley, Goldman Sachs, Lehman Brothers or Bears Stearns would encourage the mortgage banks countrywide to make home loans, often providing the capital and then the Huge Investment Banks (HIBs), would purchase these loans and package them into large securities called the Residential Mortgage Backed Securities (RMBS).

\section{iii. Excessive Leverage}

Global economic outlook (2008) reported that the final problem came from excessive leverage. Investors bought mortgagebacked securities by borrowing. Some Wall Street Banks had borrowed 40 times more than they were worth. In 1975, the Securities Exchange Commission (SEC) established a net capital rule that required the investment banks who traded securities for customers as well as their own account, to limit their leverage to 12 times. However, in 2004 the Securities and Exchange Commission (SEC) allowed the five largest investment banks - Merrill Lynch, Bear Stearns, Lehman Brothers, Goldman Sachs and Morgan Stanley - to more than double the leverage they were allowed to keep on their balance sheets, i.e. to lower their capital adequacy requirements. The institutions that have reported huge losses are those which are highly leveraged. Leveraged investors have had to return the money they borrowed to buy everything from shares to complex derivatives. That sends financial prices even lower. All this led to massive bailout packages in USA, as the government stepped in to buy and lend in a financial market. The role of leverage and credit is, therefore, central to growth. Yet, excessive leverage is fraught with dangerous consequences.

\section{iv. Mismatch between Financial Innovation and Regulation}

It is not surprising that governments everywhere seek to regulate financial institutions to avoid crisis and to make sure a country's financial system efficiently promotes economic growth and opportunity. Striking a balance between freedom and restraint is imperative. Conway (2009) reported that the financial innovation inevitably exacerbates risks, while a tightly regulated financial system hampers growth. When regulation is either too aggressive or too lax, it damages the very institutions it is meant to protect.

\section{v. Fair value accounting rules}

Fair value accounting rules require banks and others to value their assets at current market prices. The broad aim of fair value accounting is to enable investors, financial system participants, and regulators to better understand the risk profile of securities in order to better assess their position. In order to achieve this, financial statements must, in the case of instruments for which it is economically relevant, be sensitive to price signals from markets, which reflect transaction values. Investors and regulators hold that the fair value accounting standard should not be weakened because it is a key component of accurate and fully transparent fi- 
nancial statements, which in turn are the bedrock of financial activity. But the asset holders maintain that accounting standard should be reformed to fully reflect the reality of financial activities. They have argued that in times of illiquid and falling markets, it has been difficult or impossible to value assets accurately. Singh (2009) reported that the fair-value accounting has resulted in assets being valued at distressed sale prices, rather than at their fundamental value, creating a downward spiral. The requirements of fair value accounting ensured that what began initially as a subprime crisis morphed into a general credit deterioration touching prime mortgages and causing their credit downgrades and system -wide mark downs.

\section{vi. Failure of Global Corporate Governance}

The financial system of USA has changed dramatically since the 1930s. Many of America's big banks moved out of the "lending" business and into the "moving business". They focused on buying assets, repackaging them, and selling them, while establishing a record of incompetence in assessing risk and screening for creditworthiness. Hundreds of billions have been spent to preserve these dysfunctional institutions. Singh (2008) told that nothing has been done even to address their perverse incentive structures, which encourage short-sighted behaviour and excessive risk taking. Prudential oversight was lax, allowing poor lending standards, the proliferation of non-transparent securitization structures, poor risk management throughout the securitization chain, and the build-up of excessive leverage by financial institutions. The weaknesses in prudential oversight were partly due to particular characteristics of the US financial system, such as the existence of different regulatory regimes for investment banks, commercial banks and government-sponsored enterprises (Fannie Mae and Freddie Mac), as well as the complex and fragmented supervisory architecture, comprising several federal and state agencies with competing and overlapping mandates.

\section{vii. Typical characteristics of US financial system Failure of Global Corporate Governance}

One of the reasons for current crisis in the advanced industrial countries related to the failures in corporate governance that led to non-transparent incentive schemes that encouraged bad accounting practices. Rajadhyaksha (2008) studied that there is inadequate representation and in some cases no representation of emerging markets and less developed countries in the governance of the international economic institutions and standard setting bodies, like the Basle Committee on Banking Regulation. The IMF has observed and stated in The Hindu, (March 11, 2009) that market discipline still works and that the focus of new regulations should not be on eliminating risk but on improving market discipline and addressing the tendency of market participants to underestimate the systemic effects of their collective actions. On the contrary, it has often put pressure on the developing countries to pursue such macro-economic policies that are not only disadvantageous to the developing countries, but also contribute to greater global financial instability.

\section{viii. Complex Interplay of multiple factors}

It may be said with a measure of certainty that the global economic crisis is not alone due to subprime mortgage. There are a host of factors that led to a crisis of such an enormous magnitude. The declaration made by the G-20 member states at a special summit on the global economic crisis held on 15th November 2008 in Washington, D.C. identified the root causes of the current crisis and put these in a perspective. During a period of strong global growth, growing capital flows, and prolonged stability earlier this decade, market participants sought higher yields without an adequate appreciation of the risks and failed to exercise proper due diligence. At the same time, weak underwriting standards, unsound risk management practices, increasingly complex and opaque financial products, and consequent excessive leverage combined to create vulnerabilities in the system. Policy-makers, regulators and supervisors, in some advanced countries, did not adequately appreciate and address the risks building up in financial markets, keep pace with financial innovation, or take into account the systemic ramifications of domestic regulatory actions. Major underlying factors to the current situation were, among others, inconsistent and insufficiently coordinated macroeconomic policies, inadequate structural reforms, which led to unsustainable global macroeconomic outcomes. Pan (2009) reported these developments, together, contributed to excesses and ultimately resulted in severe market disruption.

\section{Impact on Indian Economy}

Until the emergence of global crisis, the Indian economy was going through a phase of high growth driven by domestic demand growing domestic investment financed mostly by domestic savings and sustained consumption demand. In fact, consumption and saving were well-balanced. Services sector, led by domestic demand, contributed to the stability in growth. Concomitantly, inflation was also generally low and stable. This overall improvement in macroeconomic performance in India was attributed to calibrated financial sector reforms that resulted in an efficient system of financial intermediation, albeit bank-based; the rule based fiscal policy that reduced the drag on private savings; and forwardlooking monetary policy that balanced the short term trade-off between growth and inflation on a continuous basis. Additionally, the phased liberalisation of the economy to trade and capital flows along with a broadly market-driven exchange rate regime enhanced the role of external demand in supporting the growth process, simultaneously exposing the economy to the forces of globalisation. India, though initially somewhat insulated to the global developments, eventually was impacted significantly by the global shocks through all the channels - trade, finance and expectations channels. This raised the issue that whether India is more globalised than what is perceived in terms of conventional trade openness indicators. At the same time, India was also among the first to exhibit strong rebound from the global downturn as compared to many advanced economies.

\section{Impact on Indian GDP growth rate}

Below the Indian's GDP growth rate chart is given to show the impact of economic crisis on GDP growth rate for the country. Economic growth is the increase in value of the goods and services produced by an economy. It is conventionally measured as the percent rate of increase in real gross domestic product or GDP. Growth is usually calculated in real terms, i.e. inflationadjusted terms, in order to net out the effect of inflation on the 
price of the goods and services produced. Indian GDP growth rate for last five years and for each year quarter growth rate of GDP are compared (Fig 1). It shows that global economic crisis of 2007 had impact on Indian GDP growth rate in the financial year of 2009, where GDP growth rate were lowest in first three quarter of the financial year.

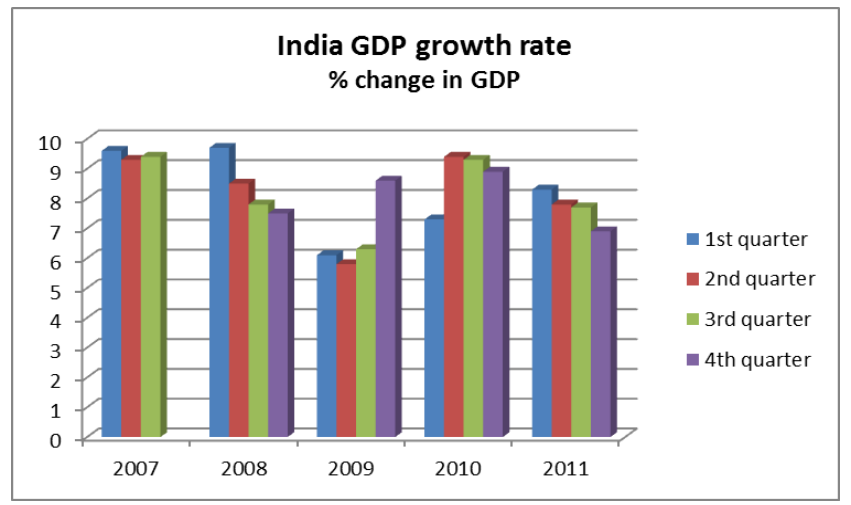

Fig.1- GDP growth rate for last five financial year

\section{Impact on Inflation rate}

By January 2010, the domestic growth signals were pointing towards a consolidation of the recovery process. However, sustained increase in food prices was beginning to spill over to manufactured products. Inflation in primary commodities moved up 8.2 in August 2009 to 22.2 per cent by March 2010. An important concern from the point of view of inflation management is the downward rigidity in the primary food articles prices even after a good monsoon. Moreover, the consumption basket is getting diversified more in favour of non-cereals items such as milk, meat, poultry, fish, vegetables and fruits, which are important from the nutritional angle. The decomposition of food inflation indicates that during the recent period the key drivers of food inflation are noncereals. All together Inflation rate is increasing at higher rate.

\section{Impact on Indian FDI inflows}

Foreign Direct Investment (FDI) inflow into the core sectors plays a significant role as a source of capital, management, and technology in transitional economies. It implies that FDI can have positive effects on the host economy's developmental efforts. As mentioned earlier, India has opened its economy and has allowed the entry of multinational corporations (MNCs) as a part of the reform process started in the beginning of 1990s. Like many other countries, India has offered greater incentives to encourage FDI inflows into its economy. The presence of FDI inflow in India was negligible till 1991, but there has been a steady build-up in the actual FDI inflows in the post-liberalisation period. The share of FDI in GDP was merely 0.03 per cent in 1991, which rose to about 3 per cent in 2009-10. Its annual growth during this period was phenomenal. The FDI inflow has been growing rapidly since then with a quantum jump after 2004-05. From US $\$ 3250$ million in $2004-05$, the FDI has leaped to over US $\$ 247329$ million in 200809. However, since February 2008, a reversal in the trend has been observed. A perusal of the monthly inflow of FDI between January 2008 and January 2010 suggests a clear decline over a period of 24 months.

The share of agriculture in the total FDI in India is negligible. The recent data show that agriculture accounted for only about 1.5 per cent of the total FDI inflows into India. In the agriculture sector, die entry of FDI was confined to plantation crops, food processing industries, agricultural services and agricultural machinery. FDI has been allowed in fertiliser manufacturing also, which have a direct bearing on agriculture but was not allowed in the cultivation of crops or rearing of livestock. However, its entry into the food processing sector can have ramifications on the agriculture sector (though it may be limited). Therefore, though the FDI inflow has slowed down over the past one year, its impact would not be visible on agriculture, as the dependence of agriculture on $\mathrm{FDI}$ is minimal (Fig 2).

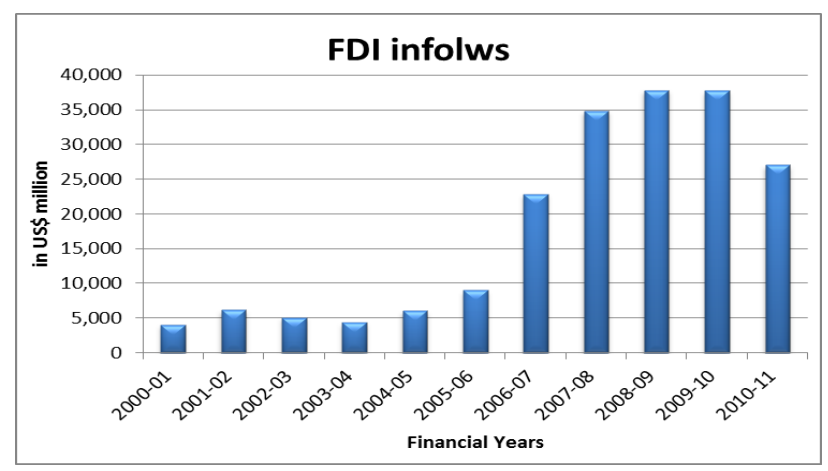

Fig 2- Trend of FDI inflows in India

\section{Impact on Export and Import}

Global crisis also affect the Indian export-import market. In 200809, export-import both had been reduced due to crisis of 2007. In fact in 2009-10 export and import of India reached in negative. Demand for Indian product has reduced in international market as a result export gone under negative in 2009-10.

\section{Impact on Indian Agriculture}

India has opened its market since the beginning of the past decade (more precisely since July 1991) by lowering tariff and nontariff barriers, as well as liberalising investment policies. Still Indian agriculture is far less vulnerable to the external economic shocks than agriculture in many developing countries. Agricultural trade still accounts for less than 10 per cent of agricultural gross domestic product (Ag. GDP). However, Indian agriculture cannot be completely insulated from the global and domestic economic recessions. The impact of economic crisis is transmitted through three distinct channels, viz., financial sector, exports and exchange rates, and the impact manifests itself in several direct and indirect ways. Some of the implications of the economic crisis are discernible in the short-run, while others may be visible only in the long run. It is difficult to gauge the impact of economic crisis on Indian agriculture in the short run. However, the trends in some broad parameters may indicate its implications and the possible options can be worked out to mitigate its adverse impact. Chandrasekhar (2009) identified the broad indicators for assessing the impact of economic recession on Indian agriculture could be the trends agricultural exports, Ag. GDP, agriculture export \& Foreign Direct Investment (FDI) etc. The trends in these indicators have been assessed and briefly discussed in the following sections. 


\section{Agricultural Exports}

Two remarkable developments have taken place in India's agricultural exports during the post-liberalisation period. one, the agricultural exports have grown at a much faster rate since the initiation of liberal economic policies where agricultural exports in value terms have grown annually from 18.9 per cent during 1990s to 15.2 per cent during 2000 s but after 2000 it reduced gradually (Table 1).

It would be interesting to see whether mere has been any divergence from the long-term trend in the export of important agricultural commodities due to economic recession. For this, share of export of agricultural products (including livestock products) in total national export during 2007-08 and 2009-10 can be compared. However, the decline or slowdown in exports cannot be entirely attributed to the economic recession.

Table 1- Trend of agricultural export, 2000 to 2010

\begin{tabular}{|llll|} 
Year & $\begin{array}{l}\text { Agriculture } \\
\text { Exports }\end{array}$ & $\begin{array}{l}\text { Total Nation- } \\
\text { al Exports }\end{array}$ & $\begin{array}{l}\text { \% Agriculture Exports to } \\
\text { Total National Exports }\end{array}$ \\
\hline $2000-01$ & 28657.37 & 201356.45 & 14.23 \\
$2001-02$ & 29728.61 & 209017.97 & 14.22 \\
$2002-03$ & 34653.94 & 255137.28 & 13.58 \\
$2003-04$ & 37266.52 & 293366.75 & 12.70 \\
$2004-05$ & 41602.65 & 375339.53 & 11.08 \\
$2005-06$ & 49216.96 & 456417.86 & 10.78 \\
$2006-07$ & 62411.42 & 571779.28 & 10.92 \\
$2007-08$ & 79039.72 & 655863.52 & 12.05 \\
$2008-09$ & 85951.67 & 840755.06 & 10.22 \\
$2009-10$ & 89522.59 & 845125.21 & 10.59 \\
\hline
\end{tabular}

\section{Agricultural GDP}

The trend in agricultural GDP during the past two decades suggests that the sector has been growing slowly and steadily, but with occasional slumps. The reasons for slow growth during the 1990 s and early 2000 s are many, ranging from poor monsoons to depressed agricultural commodity prices in the world market.

The current crisis is expected to have a modest effect on the GDP of agricultural and allied products. Recent trends indicate that the sector is not witnessing similar growth achieved during the previous year. Agricultural GDP is declined by -0.1 per cent in 2008-09 as compared to 5.8 per cent in 2007-08. In 2009-10 and 2010-11 GDP growth rate for agriculture sector was 0.4 percent and 6.6 percent respectively, Economic survey of India (2011). The trends in Ag.GDP seem to have weak links with the present recession (Fig 3).

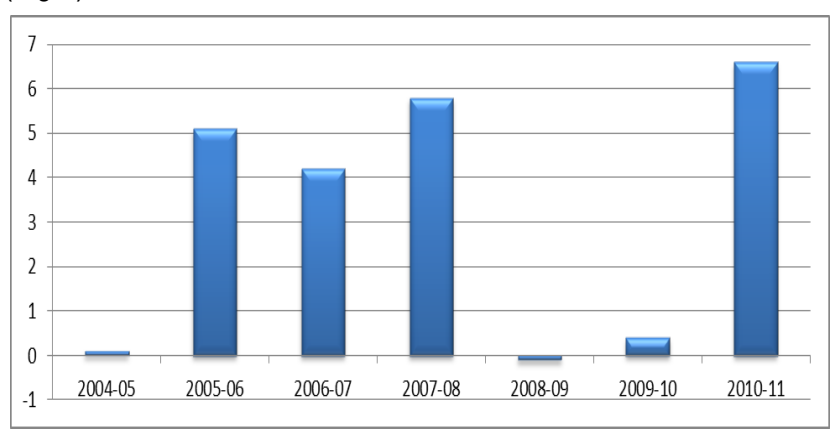

Fig. 3- GDP growth rate of agri-allied sectors

Agricultural growth has been accorded priority to improve the distributional aspects by which several schemes like National
Food Security Mission, Rashtriya Krishi Vikas Yojana (RKVY), substantial increase in the flow of agricultural credit, waiving off agricultural loans, etc. have been launched to foster growth in this sector. These schemes are likely to taper off the adverse impact of the economic recession on agriculture to a large extent. However, the economic crisis may put downward pressure on farm production in the short-run. Even though the government provides a shield to the farmers by intervening in the agricultural markets to realise stabilised income, its intervention is limited to a few commodities in some states. Therefore, in spite of government's efforts, farm income is expected to have slightly adverse impact due to economic recession. It is important to note that rainfall and other weather parameters influence agricultural growth significantly.

\section{Impacts on Fisheries \\ Economic Crisis in Fisheries}

Roughly speaking, the Asian Economic Crisis gives negative impacts to fisheries and any fisheries-related business. In domestic fish markets, demand for fisheries products is on sharp decline. Wholesale and retail prices sharply fall down. Export of Indian fisheries products mainly for Asian markets is in a severe slump. Exporters, processing companies, and any type of fish dealers suffer from extreme market slump. Their financial positions get worse, which causes a sharp decline in fish prices in production sites. Moreover, fishers and fish farmers find it very hard to raise capital for investment and operation, by depending on fish traders. Since prices of productive materials rise, the rate of profit decreases. Before the Crisis, exporters were prevented from further expansion of trading products with lower additional value. In a much contrast, domestic-oriented production remained in depression.

\section{Impact on Fisheries Export}

However, the decline or slowdown in exports cannot be entirely attributed to the economic recession. Quantity exported in the year of 2006-07 was 612 thousand tonnes and it has been reduced in the year 2007-08 to 541 thousand tonnes (Table 2), it shows the negative impact of economic crisis on fisheries export. However, after the outbreak of global Economic Crisis, demand for Indian fisheries has suddenly declined in foreign markets. It is reported that, in European Union, wholesale prices of Indian fishes imported sharply fall down. Collectors have to reduce their scale of transaction and reduce purchase prices of Indian fishes/ shrimp. Farm gate price is almost half of the highest at peak. This causes damage to small-scale fishers who are engaged in catching fry and young fish.

Table 2- Trend of fisheries export

\begin{tabular}{|lll|}
\hline Year & Export of marine products \\
& Qty ('000 tonnes) & Value (Rs in crore) \\
$2006-07$ & 612 & 8363 \\
$2007-08$ & 541 & 7620 \\
$2008-09$ & 602 & 8608 \\
$2009-10$ & 664 & 9921 \\
Source: & Economic survey, 2011 & \\
\hline
\end{tabular}

\section{Conclusion}

While the developed world, including the U.S, the Euro Zone and 
Japan, has plunged into recession, the Indian Economy is being affected by the spill-over effects of the global financial crisis, Chidambaram (2008) \& Seshan (2008). Great savings habit among people, strong fundamentals, strong conservative and regulatory regime have saved Indian economy from going out of gear, though significant parts of the economy have slowed down and there is a wide variance of opinion about how long it will continue. It is expected that growth will be moderate in India. The most important lesson that we must learn from the crisis is that we must be self-reliant. Though World Trade Organization (WTO) propagates free trade, we must adopt protectionist measures in certain sectors of the economy so that recession in any part of the globe does not affect our country.

\section{Acknowledgement}

Authors are highly grateful to Dr. W.S. Lakhra, Director, CIFE, Mumbai for proving us need full facilities for preparation of this manuscript and also thanks to Dr. R.S. Biradhar, Joint Director, CIFE, Mumbai for his support and valuable suggestions.

\section{References}

[1] Acharya S. (2009) Gloabal crisis, India and Agriculture, 9th convocation, Rajasthan Agriculture University (RAU).

[2] Chandrasekhar C.P. and Ghosh Jayanthi (2008) India and the Global Financial Crisis. From http://www.macroscan.org.

[3] Chidambaram P. (2008) Spill - over effects of global crisis will be tackled. The Hindu, Daily, 15.

[4] Conway E. (2009) WEF, Global crisis has destroyed 40pc of world wealth, Internet edition.

[5] Declaration of the G-20 Summit on Financial Markets and the World Economy 2008, Washington DC.

[6] Economic survey of India, 2011.

[7] Global Economic Outlook, 2008.

[8] Green D., King R. and Dawkins M.M. (2010) Impact and Response, Oxfam Research Report.

[9] Horn Z.E. (2010) Women in Informal Employment, Globalizing and Organizing (WIEGO).

[10]IMF (2011) World economic outlook update, rapidly weakening prospects call for new policy stimulus. Washington, DC.

[11]Kunt D., Asli and Enrica Detragiache (2002) J. of Mone. Econ., 49 (7), 122-126.

[12]Pan P.P. (2009) Economic Crisis Fuels Unrest in East Europe, The Washington Post.

[13]Rajadhyaksha N. (2008) The Hindustan Times.

[14]RBI's Bulletin (2011) Foreign Investment Inflows, Table No. 44.

[15]Seshan P.A. (2008) Concern over impact of U.S. crisis, The Hindu, 44.

[16]Seshan P.A. (2009) The Hindu (Editorial), 35.

[17]Singh N.K.. (2008) The Hindustan Times.

[18]Singh N.K. (2009) Mail Today.

[19]UNCTAD (2008a) World Investment Prospects Survey. New York and Geneva. 